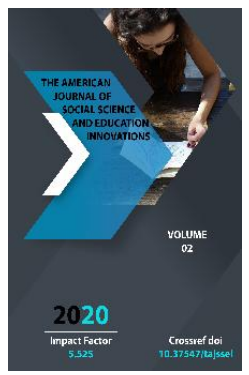

Journal Website: http://usajournalshub.c om/index,php/tajssei

Copyright: Original content from this work may be used under the terms of the creative commons attributes 4.0 licence.

\section{Teaching English As A Second Foreign Language}

\author{
Nargiza Satullaeva \\ English Language Teacher At English Language And Literature Department, Karakalpak State \\ University Named After Berdakh, Nukus, Karakalpakstan, Uzbekistan. \\ Gulperi Kurbanbaeva \\ Student At English Language And Literature Department, Karakalpak State University Named \\ After Berdakh, Nukus, Karakalpakstan, Uzbekistan.
}

\title{
ABSTRACT
}

The paper deals with the practical issues of multilingual approach to teaching foreign languages. The author investigates of some questions concerning the process of teaching English as the second foreign language based on the first language - the German language. The process under study is rather complicated. It requires taking into consideration the linguistic experience of students. In addition, this process should be based on the results of the comparative-contrastive analysis of the contacting languages: English, German and Russian (the Mother Tongue of the students). This phenomenon may be called an educational forming multilinguism of which interference and transference are characteristic features. In order to overcome the latter and to improve the educational process, comparative study of language phenomena is necessary. Having found out similar and dissimilar features in both languages the teacher will be able to optimize the learning process of the second language.

\section{KEYWORDS}

Multilingualism, comparative-contrastive analysis, interference, second foreign language, transposition, adaptive and compensatory skills, grammar phenomena.

\section{INTRODUCTION}

Teaching two or more foreign languages has become the vital requirement of modern society, as there is not always one enough foreign language of high mobility and sociability of greater part of population of earth. Over the past decades, English has 
taken the place of the world language, without which it is impossible to imagine many spheres of life, including Global network - Internet. Therefore, in all educational establishments, both at high general school and in higher educational establishment, in accordance with education programs two and more than foreign languages are taught. Being a labour intensive enough process, teaching two and more than languages requires from the teacher of foreign language another relation and approach to the educational process.

The subject of the research is ways of increasing the efficiency of the methodological system of teaching English as a second foreign language based on the use of transposition, limiting the interference of the first foreign language and Russian.

The purpose of the work is to analyze the process of teaching two foreign languages English and German, which, in our opinion, should be based on a comparative analysis of the target languages, the results of which form the basis of the educational process and help teachers coordinate their work and achieve positive results.

Similarities and distinctions of the phonetic, lexical and grammatical systems of the languages studied in parallel not only help students better to understand and master the studied language phenomena and processes but also assist development of linguistic conjecture, broaden their horizons and increase motivation. Comparative study of two foreign languages is also useful for a deeper understanding of the linguistic phenomena and processes occurring in the Russian and native languages of students.

\section{Materials And Methods}

"Every language must be examined as something fully self-sufficient, and only after for methodical purposes, to facilitate the mutual learning it is possible to make a comparison of two language systems" [6, p. 318]. According to many scientists [V.D. Arakin O.S. Akh-manova, V.G. Gak, V.N. Yartseva, R. Yu. Badger, L.S. Barkhudarov et al.], the inclusion of comparative analysis in the process of teaching two or more foreign languages promotes an acceleration and deepening of process of understanding, memorizing and automation of language and students' speech skills and of abilities.

The use of comparative analysis for linguodidactic purposes requires, foremost, to define methodically relevant similarities and distinctions between the compared languages. It is then necessary to define the type of interlingual interference, and what difficulties can arise up as a result of interlingual distinctions. On the final stage there is a necessity of creation of an exercise system based on interlingual comparison as reception of educating to the non-native language.

Comparison of the studied languages in didactic aims allows the teacher to define the difficulties related to the features of different languages, and to find the ways to overcome difficulties. In addition, for those studying a second or third foreign languages, such training manual us required that would be based on the results of a comparative analysis and take into account distinctions and similarities of the studied languages, which must be reflected in the exercise system and the delivery of material. 
The theoretical issues of the simultaneous teaching of two or more foreign languages are dealt with by "multilingual didactics, i.e. the theory of teaching multilingualism, the subject of which is the study of optimal methods, techniques, methods of teaching several foreign languages simultaneously or sequentially in different conditions and for different learning purposes" [3].

Baryshnikov N.V. defines the principles of teaching multilingualism, underlying the professional training of a modern multilingual linguist as follows:

- The principle of integrative teaching in several languages;

- The principle of co-learning of several languages;

- The principle of reliance on the linguistic and educational experience of trainees;

- The principle of the cognitive orientation of the learning process of FL;

- The principle of intercultural orientation of the learning process of foreign languages, etc. [4].

Students' mastering a foreign language does not occur spontaneously, as mastering of the mother tongue, but is carried out in an organized manner, in three stages - preschool education (kindergarten), school education (junior, secondary and senior secondary schools) and a university. Unlike the native language, a foreign language presents for students a certain social, cultural and cognitive reality, with which students do not have the opportunity to contact constantly. Therefore, many scientists define this type of multilingualism as an artificial formed educational multilingualism [5]. One of the main requirements of the methodology has always been the creation in various ways in the lesson of natural situations for foreign language communication. However, at present, widely using multimedia and technical teaching aids, the teacher has the opportunity to create an authentic language environment in foreign language classes.

The process of teaching two or more languages is difficult and labour intensive, because the study of the first foreign language is always based on the transfer of some language and speech skills and abilities from the native language. In some cases, this phenomenon produces a positive effect (the phenomenon of transfer), but in most cases it brings negative results (the phenomenon of interference), and interferes with the correct perception of the language material. As for the second foreign language, the skills and abilities acquired by students in the study of the first foreign language, as well as the linguistic experience formed by the students on the basis of their native language, have a double influence on it.

There is such a phenomenon as transposition at the study of foreign language. Transposition is a positive transfer of knowledge, skills and abilities of students in their native language to the target language, and the use of existing linguistic experience during classes in a foreign language, while not causing violations of its norms in the target language [2].

In addition to the transfer, with the simultaneous teaching of two languages, there is interference, which manifests itself in the violation of the norms of a foreign language under the influence of linguistic phenomena of the native or another studied language. The more differences between language systems, the more often the interference is observed. 
The phenomenon of interference is observed in the process of teaching phonetics, vocabulary, grammar - language skills, and in the process of teaching speech skills listening, reading, writing, speaking. In addition, interference often manifests itself at the socio-cultural level due to insufficient knowledge of the cultural characteristics of the country of study.

Similar in different cultures realities, phenomena, codes of conduct can cause interference, for example, different forms of speech etiquette. So, in the Russian language "please" is used as a formula of politeness, meaning "not at all", which is used as an answer to "thank you". In English and German, "please" and "bitte" do not have these meanings. In English, the word "please" has several variants, depending on the situation: Not at all. - please (not worth it); Here you are. - Please (when giving anything), Please - used in a polite request.

\section{RESULT AND DISCUSSION}

The process of teaching the phonetic structure of the English language is often hampered by the influence of German. Such a phonetic phenomenon as a Glottal Stop, characteristic of the German language, and absent in English, is observed in the speech of students not only at the initial stage of training, but requires significant efforts from the teacher. In addition, the speech of students is peculiar to the stunning of voiced consonants (Devoicing of Voiced consonants); non-observance of vowel length (Long and short vowels); replacement of interdentals with similar sounds $[\mathrm{t}][\mathrm{d}]$.

Lexical interference is the use of a foreign language vocabulary in dialogical or monologue speech in a native or first foreign language. When learning English as a second foreign language based on the first language German, the source of interference is usually the first foreign language. Some lexical units of foreign languages are very alike, therefore at the similar terms of mastering of lexemes probability of such interference is great. For example, the German verb of bekommen (to get) by analogy with the English verb of to become acquires in speech of student value to become.

In the two studied languages, there are a number of lexemes that completely coincide in terms of the scope of their meanings. These are the names of the days of the week, names of months, seasons, some numerals, some verbs, etc.

For example: English German

Monday Montag

Winter Winter

May Mai

Four vier

Hundred hundert

To dance to dance

The indicated layer of vocabulary does not require time and special explanation, and is easily memorized by students.

Except errors caused by the interfering influence of the German and Russian languages, there is a phenomenon of intralingual interference in the English speech of students. A fairly large number of groups of lexical units can be distinguished, within which there is an erroneous semantisation occurring due to the proximity of the sound and spelling of words. For example: live - leave; live - life; bed - bad; fall - feel; wonder - wander; hungry angry; angry - agree; snack - snake; like - lick; mouse - mouth; lie - lay; and etc.

The grammatical phenomena of the second foreign language also require comparing to 
the already known phenomena of the first foreign language. When teaching English on the basis of the first German, i.e. two Germanic languages, students can quite easily memorize the forms of regular and irregular English verbs by analogy with strong and weak German verbs. For example, the English verb to have -had -had corresponds to the German verb haben - hatte-gehabt.

For example, comparing the English verb to be and the German sein, learners will not have difficulty memorizing the forms, understanding the meaning of this verb and its function. Memorizing the degrees of comparison of adjectives is not difficult. For example: English adjective many | much - more - the most corresponds to the German viel mehr - am meisten.

Some English grammatical constructions are also easily memorized by students by analogy with German.

It is warm... Es ist warm...

There is... Es gibt...

The use of some times may not cause much difficulty. For example, the use of the present tense to express future actions in English, German and Russian.

The train starts at $5 \mathrm{o}^{\prime}$ clock. Der Zug fährt um 5 Uhr ab. Поезд отправляется в 5 часов

In both English and German, the infinitive after some verbs is used with the particle zu (to).

For example: He began to read. Er begann zu lesen.

After modal verbs, the infinitive is used without the to particle in English and German.
For example: She must read a book. Sie muss ein Buch lesen.

However, there may be some difficulties in teaching English as a second foreign language, related to divergence of some grammatical phenomena. For example, cases in German are 4, in English 2; the number of times - in German 5, in English 16; articles of masculine, feminine and neuter in German (Der, Die, Das) and definite and indefinite articles in English (a l an, the).

Another example of the inconsistency of the grammatical phenomenon in two languages: the observance of the framework structure in the construction of a sentence in the passive voice and for any complex predicate in German, unlike the direct order of words in English.

For example: Er hatgestern die Hausaufgabe nicht gemacht.

He did not do his homework yesterday.

On all groups of the phenomena distinguished higher it is necessary to pay attention in learning English as to the second foreign language. To make the learning process pass more effective, it is required to prepare special exercises and tasks, which will gradually help to reduce the interfering influence of the first and native languages.

To overcome the interference, specially selected exercises are required, compiled in one foreign language, and requiring compulsory use of the second foreign language. Thus, the student will be able to project knowledge from one language into the second, compare their similarities and differences.

For example: 


\section{Exercise 1:}

Underline the suffixes and identify the parts of speech for the following words. Translate into Russian and German and compare the ways of forming the following parts of speech in the compared languages.

\section{Exercise 2:}

From the proverbs given below will distinguish a few antonymous words. Pick up the Russian and German analogues to them, comment on distinctions and similarities in their values.

\section{Exercise 3.}

Form the degrees of comparison of the following adjectives and adverbs. Translate into Russian and German and compare the ways of generating degrees of comparison in the compared languages.

\section{Exercise 4.}

Fill in the gaps with words in English. Translate into Russian and German and compare the ways of forming degrees of comparison in three languages.

\section{Exercise 5.}

Translate into Russian and German and explain the reason for the differences in the use of temporary forms, etc.

\section{Exercise 6.}

Translate sentences from Russian into English, then into German. Note (or compare) the use of prepositions with verbs in three languages.

\section{Exercise 7.}

Ask questions about highlighted words in English and German sentences. Explain what is the difference in the formation of interrogative sentences in the target languages.

\section{CONCLUSION}

These kinds of exercises contribute to the development of language conjecture, facilitate the process of memorizing and accelerate the study of the pre-arranged educational material. Thus, we can conclude that when teaching English as a second foreign language, a comparative analysis is needed, which will help students identify both similarities and differences between the three languages that function in the educational process. Comparison of linguistic phenomena should be carried out at all language levels and at all stages of learning.

Mastering several foreign languages is not an isolated process, but an interconnected and interdependent simultaneous study of languages, based on the results of a comparative analysis of languages and on the linguistic experience of students.

\section{REFERENCES}

1. Barsuk R.Yu. Osnovi obucheniya inostrannomu jaziku $v$ usloviyah dvujazichiya[The basics of a foreign language teaching in bilingual condition]. M.; Visshaja Shkola, 1970. $176 \mathrm{p}$.

2. Barsuk R.Yu. Sopostavitel'nie i tipologicheskie issledovanija kak lingvisticheskaja osnova obucheniya vtoromu i tret'emu jazikam[Comparative and typological research as Linguistic basis of teaching the second and the third languages]. M., 1971. P.I, pp. 24-30.

3. Barishnikov N.V. Metodika obucheniya vtoromu inostrannomu jaziku [Methods of teaching the second foreign language]. M.: Prosveshenie, 2003. 
4. Barishnikov N.V. Multilingvodidaktika [Multilinguodidactics]. Inostrannie Jaziki v Shkole, № 5. 2004, pp. 19-27.

5. Dzhioeva A.R. Teoretikometodologicheskie i lingvisticheskie osnovi formirujushegosja uchebnogo mnogojazichija [Theoreticalmethodological and linguistic foundations of developing educational multilinguism]. Vladikavkaz, 2004. 165

p.

6. Harmer J. The practice of English language teaching. NewYork: Longman, 1991. P.p. 56-78

7. Scherba L.V. O vzaimootnoshenijah rodnogo i inostrannogo jazikov [About interrelations of a mother tongue and a foreign language]. Jazikovaja sistema i rechevaja dejatel'nost'[Language system and speech activity]. L., 1974. P. 343. 